\title{
ANTIPSORIASIS, ANTIOXIDANT, AND ANTIMICROBIAL ACTIVITIES OF AERIAL PARTS OF EUPHORBIA HIRTA
}

\author{
CAROLINE JEBA $\mathbf{R}^{1 *}$, ILAKIYA A $^{1}$, DEEPIKA ${ }^{1}$, SUJATHA $\mathbf{M}^{1}$, SIVARAJI $\mathrm{C}^{2}$ \\ ${ }^{1}$ Department of Biotechnology, Dr. M.G.R. Educational and Research Institute, Maduravoyal, Chennai - 600 095, Tamil Nadu, India. \\ ${ }^{2}$ ARMATS Biotek Training and Research Institute, Chennai - 6000 032, Tamil Nadu, India. Email: janeshjeba@gmail.com
}

Received: 30 April 2018, Revised and Accepted: 09, July 2018

\section{ABSTRACT}

Objectives: The aim of the study was curing antipsoriasis through Euphorbia hirta. The antipsoriasis activity was done by the 3-[4,5-dimethylthiazol2-yl]-2,5 diphenyl tetrazolium bromide (MTT) assay method.

Methods: Aerial parts were shade, dry for 2 days, make into coarse powder and soaked in methanol for $72 \mathrm{~h}$. The supernatant liquid was filtered by Whatman filter paper and condensed in a hot plate at $50^{\circ} \mathrm{C}$. Dark gummy mass obtained. The study identified the antioxidant, antimicrobial, and antipsoriasis activities of methanol extract of aerial parts of $E$. hirta.

Results: The IC ${ }_{50}$ value of methanol extract of aerial parts was found to be $72.20 \mu \mathrm{g} / \mathrm{mL}, 97.88 \mu \mathrm{g} / \mathrm{mL}, 55.88 \mu \mathrm{g} / \mathrm{mL}$, and $36.31 \mu \mathrm{g} / \mathrm{mL}$ by 1,1 -diphenyl2-picrylhydrazyl radical scavenging assay, superoxide radical scavenging assay, phosphomolybdenum reduction assay, and ferric (Fe ${ }^{3+}$ ) reducing power assay. The antipsoriasis activity was done by the MTT assay method. The maximum cell death was $88.37 \%$ observed at $0.781 \mu \mathrm{g} / \mathrm{mL}$ concentration and $\mathrm{IC}_{50}$ was $12.20 \mu \mathrm{g} / \mathrm{mL}$ concentrated.

Conclusion: The results of the present investigation reveal the antipsoriasis activity of the extracts of $E$. hirta against bacteria and viruses, the psoriasis causing organisms. The methanol extract of $E$. hirta shows antioxidant, antimicrobial, and antipsoriasis activity and can be used to formulate a potential therapeutic agent for psoriasis.

Keywords: Euphorbia hirta, Antioxidant, Antimicrobial, Anticancer; HaCaT, 3-[4,5-dimethylthiazol-2-yl]-2,5 diphenyl tetrazolium bromide assay.

(C) 2018 The Authors. Published by Innovare Academic Sciences Pvt Ltd. This is an open access article under the CC BY license (http://creativecommons. org/licenses/by/4. 0/) DOI: http://dx.doi.org/10.22159/ajpcr.2018.v11i9.26974

\section{INTRODUCTION}

Euphorbia hirta belongs to the family Euphorbiaceae. Medicinal plants are used to cure various diseases in India since ancient times. The indigenous system of the medicine, namely Ayurvedic, Siddha, and Unani, has been in existence for several centuries. Some drugs from Ayurveda approaches modern diseases have already reached the marketplace [1]. In modern medicine, plants occupy a very important place as the raw material for some important drugs. Synthetic drugs are effective in controlling different diseases, but these synthetic drugs are out of reach of millions of people. It is estimated that around 70,000 plant species had been used for medicinal purposes. The plant herbs provide the starting material for synthesis of conventional drugs. Medicinal plants have curative actions due to the presence of complex chemical composition. India recognizes more than 2500 plant species having medicinal value, Sri Lanka around 1400, and Nepal around 700 [2]. This review intends to provide an overview of chemical composition and pharmacological actions of plant E. hirta.

E. hirta is commonly known as asthma plant (or) snakeweed. The common name is Amman pacharisi. It is a medicinal rhizomatous herb distributed in southern the Western Ghats of India and also in the Northern east Coast of Tamil Nadu [3]. E. hirta has a long history as a medicinal herb in China. Different formulations are used, including crude drug, decoction, infusion, lotion, and powder. It plays a very important role of traditional Chinese medicine, especially in the folk medicine because of its wide range of biological and pharmacological products [4].

\section{METHODS}

Collection of plant material

The aerial parts of Euphorbia hirta were received from agricultural land (Periyapalaiyam), Chennai, Tamil Nadu, India. The plant was authenticated by Prof. P. Jayaraman, Director, Institute of Herbal Botany, Plant Anatomy and Research Centre, Chennai- 45.

\section{TAXONOMY}

Kingdom: Plantae

Division: Angiosperms

Class: Eudicots

Subclass: Rosids

Order: Malpighiales

Family: Euphorbiaceae

Species: E. hirta

Genus: Euphorbia

Binomial name: Euphorbia hirta

\section{Preparation of the plant extract}

The aerial parts were dried in shadow for 2 days, at room temperature. The sample was soaked in $500 \mathrm{~mL}$ of methanol at the room temperature. The supernatant was filtered using filter paper and allowed for condensation using a hot plate until the extract reaches a semi-solid state.

\section{Antioxidant assays}

1,1-diphenyl-2-picrylhydrazyl (DPPH) ' radical scavenging assay The antioxidant activity of methanol extract of the aerial parts of Euphorbia hirta has evaluated through free radical scavenging effect on DPPH radical. The determination was based on the method proposed by Akowuah et al. [5]. $1 \mathrm{~mL}$ of $0.1 \mathrm{mM}$ of DPPH in the methanol solution was mixed with $1 \mathrm{~mL}$ of $(20-120 \mu \mathrm{g} / \mathrm{mL})$ sample extracts. The mixture has completely added and kept in the dark for $30 \mathrm{~min}$. The control was prepared by adding $1 \mathrm{~mL}$ of DPPH and $1 \mathrm{~mL}$ methanol. The absorbance was calculated at $517 \mathrm{~nm}$ using a spectrophotometer. Percentage of 
DPPH radical scavenging activity was calculated as follows:

$\%$ of DPPH radical inhibition $=\left(\frac{\text { Control }- \text { Sample }}{\text { Control }}\right) * 100$

\section{Superoxide radical scavenging assay}

Superoxide radical, known to be very harmful to cellular components as a precursor of the more reactive oxygen species, contributes to tissue damage and many diseases [6]. In a biological system, its toxic role can be eliminated by superoxide dismutase. The radicals may also play an important role during the peroxidation of unsaturated fatty acids and other potential susceptible substances. Superoxide is biologically quite toxic and is deployed by the immune system to kill invading microorganisms. It is an oxygen-centered radical with selective reactivity.

It also produced by a number of enzyme systems in auto-oxidation reactions and by non-enzymatic electron transfers that univalent reduces molecular oxygen. The biological toxicity of superoxide is due to its capacity to inactivate iron-sulfur cluster-containing enzymes, which are critical in a wide variety of metabolic pathways, thereby liberating free iron in the cell, which can undergo Fenton chemistry and generate the highly reactive hydroxyl radical. It can also reduce certain iron complexes such as cytochrome c. Superoxide anions are a precursor to active free radicals that have the potential of reacting with biological macromolecules and thereby inducing tissue damage. It has been implicated in several pathophysiological processes due to its transformation into more reactive species such as hydroxyl radical that initiates lipid peroxidation. Furthermore, superoxide has been observed to directly initiate lipid peroxidation. In addition, it has been reported that antioxidant properties of some flavonoids are effective mainly through scavenging of superoxide anion radical. Superoxide anion plays an important role in the formation of other ROS such as hydrogen peroxide, hydroxyl radical, and singlet oxygen, which induce oxidative damage in lipids, proteins, and DNA. Superoxide radical is normally formed first, and its effects can be magnified because it produces other kinds of free radicals and oxidizing agents. Superoxide anion derived from dissolved oxygen by riboflavin/methionine/illuminate system and reduces NBT in this system. In this method, superoxide anion reduces the yellow dye (NBT2+) to produce the blue formation which is calculated spectrophotometrically at $560 \mathrm{~nm}$.

The reaction mixture in various concentrations of E. hirta $50 \mathrm{mM}$ of phosphate buffer ( $\mathrm{pH} 7.8$ ), $1.5 \mathrm{mM}$ of riboflavin, $12 \mathrm{mM}$ of EDTA, and $50 \mathrm{mM}$ of NBT, added in that sequence. The reaction was started by illuminating the reaction mixture for $150 \mathrm{~s}$. Immediately after illumination, the absorbance was calculated at $590 \mathrm{~nm}$ and $\mathrm{IC}_{50}$ was calculated. Ascorbic acid has used as positive control.

$\%$ of superoxide radical cation inhibition

$=\left(\frac{\text { Control }- \text { Sample }}{\text { Control }}\right) * 100$

\section{Phosphomolybdenum reduction assay}

The antioxidant capacity of methanol extract of aerial parts of Euphorbia hirta has assessed as described by Basma et al. [7]. The extracts in dilution from 10 to $60 \mu \mathrm{g} / \mathrm{mL}$ were added to the reagent solution containing ammonium molybdate $(4 \mathrm{mM})$, sodium phosphate $(28 \mathrm{mM})$, and sulfuric acid $(600 \mathrm{mM})$. The reaction mixture was incubated in a water bath at $90^{\circ} \mathrm{C}$ for $90 \mathrm{~min}$. The absorbance of the coloured complex was measured at $695 \mathrm{~nm}$. Increased the absorbance of the reaction mixture indicates the increase in phosphomolybdenum reduction.
$\%$ of Phosphomolybdenum radical inhibition

$=\left(\frac{\text { Sample }- \text { Control }}{\text { Sample }- \text { Control }}\right) * 100$

\section{Ferric $\left(\mathrm{Fe}^{3+}\right)$ is reducing power assay}

According to the method of various concentrations of the methanol extract of the aerial parts of E. hirta $(10-60 \mu \mathrm{g} / \mathrm{mL})$ in $1.0 \mathrm{~mL}$ of methanol were reacted with phosphate buffer $(2.5 \mathrm{~mL})$ and potassium ferricyanide $(2.5 \mathrm{~mL})$ [8]. The mixture was incubated at the $50^{\circ} \mathrm{C}$ for $20 \mathrm{~min}$. Aliquots of trichloroacetic acid $(2.5 \mathrm{~mL})$, they were adding to the mixture, which have then centrifuged at the $3000 \mathrm{rpm}$ for $10 \mathrm{~min}$. The upper layer of solution (2.5 ml) was mixed with distilled $\mathrm{H}_{2} \mathrm{O}$ $(2.5 \mathrm{~mL})$ and a freshly produced ferric chloride solution $(0.5 \mathrm{~mL})$. The absorbance was calculated at $700 \mathrm{~nm}$. A blank was produced without mixing extract. Ascorbic acid was used as standard. Increased the absorbance of the reaction mixture indicates the increase in reducing power.

$\%$ of $\mathrm{Fe}^{3+}$ radical inhibition $=\frac{\text { Sample }- \text { Control }}{\text { Sample }} * 100$

\section{Antimicrobial activities}

Petri plates carrying $20 \mathrm{ml}$ Mueller-Hinton agar medium [9] were seeded with a bacterial culture. Wells of approximately $5 \mathrm{~mm}$ were bored using a good cutter and a sample of 50,75 , and $100 \mu \mathrm{g} / \mathrm{ml}$ concentrations was mixed [10]. The plates were then incubated at $37^{\circ} \mathrm{C}$ for $24 \mathrm{~h}$. The antibacterial activity was assessed by measuring the diameter of the inhibition zone formed around the well. Tetracycline was used in the positive control [11].

\section{Thin-layer chromatography (TLC)}

TLC was carried out for aerial parts of E. hirta in Merck TLC aluminum sheets, silica gel $60 \mathrm{~F} 254(20 \mathrm{~cm} \times 20 \mathrm{~cm})$, and preloaded plates. The extract was spotted at $0.3 \mathrm{~mm}$ above from the bottom of the TLC plate. The chromatogram was developed with a mixture of suitable solvent system. The spots were visualized with UV light at $356 \mathrm{~nm}$. The $R_{\mathrm{f}}$ values of the colored spots were measured. The ratio in which distinct bands appeared was optimized and $\mathrm{R}_{\mathrm{f}}$ values were calculated [12].

Calculation of $\mathrm{R}_{\mathrm{f}}$ value:

$\mathrm{R}_{\mathrm{f}}$ value $=\frac{\text { Distance travelled by the solute }}{\text { Distance travelled by the solvent }}$

Antipsoriasis activity on HaCaT cell line

3-[4,5-dimethylthiazol-2-yl]-2,5 diphenyl tetrazolium bromide (MTT) assay method

Cell viability has measured by the conventional MTT reduction assay method was described Mossman with slight modification. Briefly, $\mathrm{HaCaT}$ cells were seeded at the density of $5 \times 10^{3}$ cells/well in 96-well plates for $24 \mathrm{~h}$, in $200 \mu \mathrm{L}$ of RPMI with $10 \%$ fetal bovine serum. Then, the culture supernatant was removed, and RPMI containing various concentrations $(0.781-100 \mu \mathrm{g} / \mathrm{mL})$ of test compound was added and incubated for $48 \mathrm{~h}$. After the treatment, cells are incubated with $10 \mu \mathrm{L}$ of MTT ( $5 \mathrm{mg} / \mathrm{mL}$ ) at $37^{\circ} \mathrm{C}$ for $4 \mathrm{~h}$ and then with dimethylsulfoxide (DMSO) at the room temperature for $1 \mathrm{~h}$. The plates were read at $595 \mathrm{~nm}$ on a scanning multiwell spectrophotometer [13].

\section{RESULTS AND DISCUSSION}

\section{DPPH' radical scavenging assay}

In this day study, the antioxidant activity of methanol extract of the aerial parts of E. hirta was investigated using the DPPH radical scavenging assay. The DPPH antioxidant assay is based on the ability of DPPH, a stable free radical, to decolorize in the presence of antioxidants. The DPPH radical contains an odd electron, which is responsible for the absorbance at $517 \mathrm{~nm}$ and also for visible deep purple color. When DPPH 
accepts an electron or hydrogen donated by an antioxidant compound, the DPPH is decolorized which can be quantitatively calculated from the changes in absorbance. The methanol extract of aerial parts of exhibited a significant dose-dependent inhibition of DPPH activity. The percentage of inhibition was found to be 69.59 at $120 \mu \mathrm{g} / \mathrm{mL}$ (Table 1). The $\mathrm{IC}_{50}$ value of the methanol extract of the aerial parts of $E$. hirta was $77.52 \mu \mathrm{g} / \mathrm{mL}$

\section{Superoxide radical scavenging assay}

Superoxide radical scavenging activity was based on the capacity of the sample to inhibit blue formazan formation by scavenging the superoxide radicals generated in riboflavin-light-NBT system. Superoxide is an oxygen-centered radical with selective reactivity. Although it is a relatively weak oxidant, superoxide exhibits limited chemical reactivity can generate more dangerous species, including singlet oxygen and hydroxyl radicals, which cause the peroxidation of lipids. These species are produced by a number of enzyme systems.

Superoxide can also reduce certain iron complexes such as cytochrome C. Superoxide anions are thus precursors to active free radicals that have potential for reacting with biological macromolecules and thereby inducing tissue damage. Furthermore, superoxide has been observed to directly initiate lipid peroxidation. It has also been reported that antioxidant properties of some flavonoids are effective mainly through scavenging of superoxide anion radical. Superoxide radicals are

Table 1: DPPH radical and superoxide radical scavenging activities of methanol extract of the Euphorbia hirta

\begin{tabular}{|c|c|c|c|}
\hline \multirow[t]{2}{*}{ S. No } & \multirow{2}{*}{$\begin{array}{l}\text { Concentration } \\
(\mu \mathrm{g} / \mathrm{ml})\end{array}$} & \multicolumn{2}{|c|}{$\%$ of inhibition } \\
\hline & & $\begin{array}{l}\text { DPPH' } \\
\text { at } 517 \mathrm{~nm}\end{array}$ & $\begin{array}{l}\text { Superoxide } \\
\text { at } 590 \mathrm{~nm}\end{array}$ \\
\hline 1 & 20 & $13.06 \pm 0.91$ & $13.09 \pm 0.91$ \\
\hline 2 & 40 & $30.63 \pm 2.14$ & $28.38 \pm 1.98$ \\
\hline 3 & 60 & $41.44 \pm 2.90$ & $41.94 \pm 2.93$ \\
\hline 4 & 80 & $55.40 \pm 3.87$ & $47.61 \pm 3.33$ \\
\hline 5 & 100 & $65.76 \pm 4.60$ & $51.09 \pm 3.51$ \\
\hline 6 & 120 & $69.59 \pm 4.89$ & $60.98 \pm 4.26$ \\
\hline
\end{tabular}

DPPH: 1,1-diphenyl-2-picrylhydrazyl

Table 2: Phosphomolybdenum reduction and $\mathrm{Fe}^{3+}$ reducing power assays of methanol extract of Euphorbia hirta

\begin{tabular}{|c|c|c|c|}
\hline \multirow[t]{2}{*}{ S. No } & \multirow{2}{*}{$\begin{array}{l}\text { Concentration } \\
(\mu \mathrm{g} / \mathrm{mL})\end{array}$} & \multicolumn{2}{|l|}{$\%$ of reduction } \\
\hline & & $\begin{array}{l}\text { Phosphomolybdenum } \\
\text { reduction } \\
\text { at } 695 \mathrm{~nm}\end{array}$ & $\begin{array}{l}\text { Fe3+reducing } \\
\text { power } \\
\text { at } 700 \mathrm{~nm}\end{array}$ \\
\hline 1 & 10 & $32.96 \pm 2.30$ & $18.87 \pm 1.32$ \\
\hline 2 & 20 & $36.69 \pm 2.52$ & $31.42 \pm 2.19$ \\
\hline 3 & 30 & $40.85 \pm 2.85$ & $37.04 \pm 2.59$ \\
\hline 4 & 40 & $46.77 \pm 3.27$ & $50.08 \pm 3.50$ \\
\hline 5 & 50 & $46.82 \pm 3.27$ & $53.17 \pm 3.72$ \\
\hline 6 & 60 & $53.68 \pm 3.75$ & $54.06 \pm 3.78$ \\
\hline
\end{tabular}

Table 3: $\mathbf{R}_{\mathrm{f}}$ values of compounds separated by thin-layer chromatography of Euphorbia hirta

\begin{tabular}{ll}
\hline $\begin{array}{l}\text { Spots } \\
\text { observed }\end{array}$ & Rf value (UV 234 nm) \\
\hline 1 & \\
2 & 0.10 \\
3 & 0.24 \\
4 & 0.32 \\
5 & 0.54 \\
6 & 0.72 \\
\hline UV: Ultraviolet & 0.81 \\
\hline
\end{tabular}

normally formed first, and their effects can be magnified because they produce other kinds of free radicals and oxidizing agents.

Superoxide anions derived from dissolved oxygen by the riboflavin-lightNBT system will reduce NBT in this system. In this method, superoxide anion reduces the yellow dye $\left(\mathrm{NBT}^{2+}\right)$ to produce the formazan, which is measured spectrophotometrically at $590 \mathrm{~nm}$. Antioxidants are able to inhibit the blue NBT formation. The decrease of absorbance at $560 \mathrm{~nm}$ with antioxidants indicates the consumption of superoxide anion in the reaction mixture. The maximum superoxide reduction of leaves was 60.98 at $120 \mu \mathrm{g} / \mathrm{mL}$ concentration. The experiment demonstrated high antioxidant activity, the $\mathrm{IC}_{50}$ was $97.88 \mu \mathrm{g} / \mathrm{mL}$ and was compared with standard ascorbic acid.

\section{Phosphomolybdenum reduction assay activity}

The total antioxidant activity of methanol extract of the E. hirta was measured spectrophotometrically by phosphomolybdenum reduction method which is based on the reduction of Mo (VI) to Mo (V) by the formation of green phosphate/Mo (V) complex at acidic $\mathrm{pH}$, with a maximum absorption at $695 \mathrm{~nm}$. The maximum absorbance was 53.68 at $60 \mu \mathrm{g} / \mathrm{mL}$ concentration. It was compared with the standard (0.359) ascorbic acid.

\section{Ferric $\left(\mathrm{Fe}^{3+}\right)$ is reducing power activity}

The reducing power of $\mathrm{Fe}^{3+}$ to $\mathrm{Fe}^{2+}$ by the methanol extract of the E. hirta was studied and showed reduction ability in a dose-dependent manner. The maximum absorbance was 54.06 at $60 \mu \mathrm{g} / \mathrm{mL}$ and was compared with the standard (0.289) ascorbic acid (Figs. 1 and 2, Table 2).

\section{TLC}

TLC Thin layer chromatography (TLC) was carried out for the methanol extract of E.hirta of TLC aluminium sheets silica gel 60 F $254(20 \times 20 \mathrm{~cm})$. Natural of substance to be separated, i.e., acidic, basic, and amphoteric.

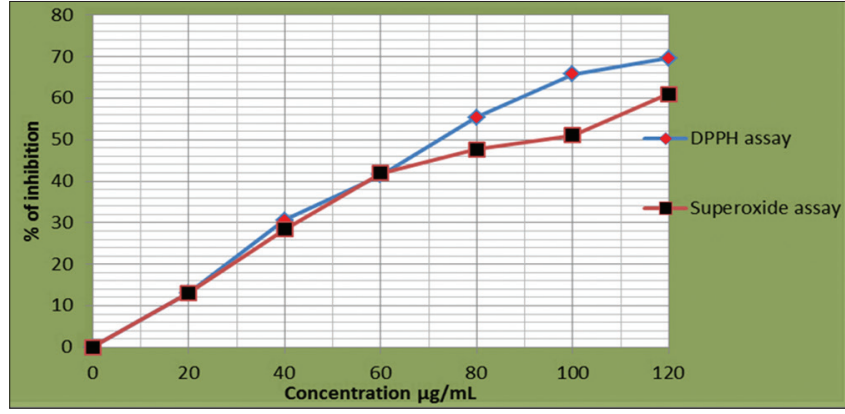

Fig. 1 Quantitative analysis of 1,1-diphenyl-2-picrylhydrazyl and superoxide radical scavenging assay of methanol extract of aerial part of Euphorbia hirta. Both assays were decreasing assay

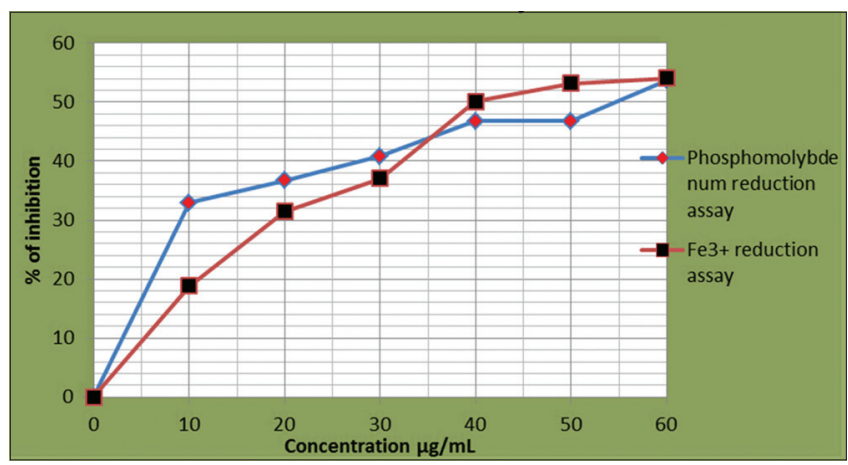

Fig. 2 Quantitative analysis of phosphomolybdenum reduction and $\mathrm{Fe}^{3+}$ reducing power assays of methanol extract of aerial parts of Euphorbia hirta. Both of the assays were increasing in the graph 
Table 4: Antimicrobial activity of aerial parts of Euphorbia hirta

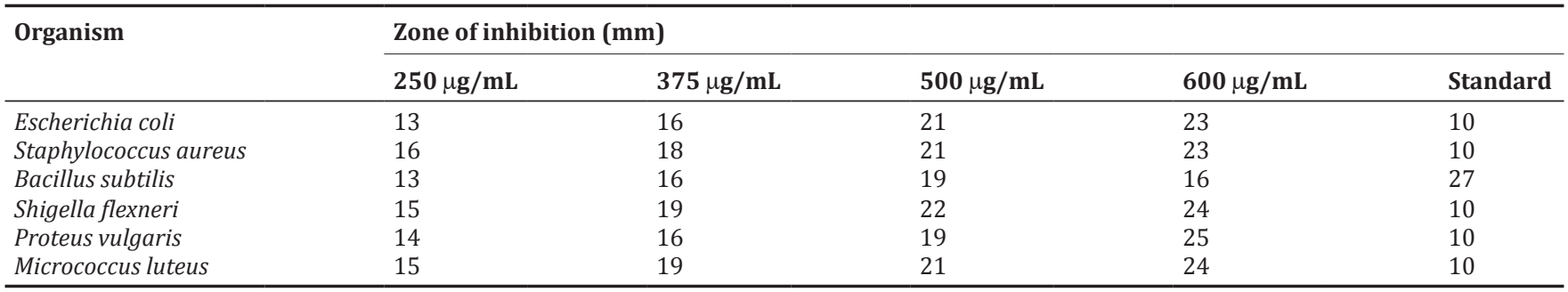

Table 5: Antipsoriasis (MTT) of methanol extract of aerial parts of the Euphorbia hirta

\begin{tabular}{lll}
\hline S. No & Concentration $(\mu \mathrm{g} / \mathbf{m L})$ & Cell death $\mathbf{( \% )}$ \\
\hline 1 & 0.781 & 88.37 \\
2 & 1.562 & 77.13 \\
3 & 3.125 & 70.96 \\
4 & 6.25 & 61.35 \\
5 & 12.5 & 48.18 \\
6 & 25 & 40.33 \\
7 & 50 & 34.23 \\
8 & 100 & 23.77 \\
9 & 250 & 16.26 \\
\hline
\end{tabular}

MTT: 3-[4,5-dimethylthiazol-2-yl]-2,5 diphenyl tetrazolium bromide

To see whether a compound is liable to react chemically with adsorbent (or solvent) or not. The separated compounds in TLC are shown in Fig. 3 (Table 3).

\section{Antibacterial activity}

Antimicrobial activity was screened against. Melica minuta extracts and the extract showed good antibacterial activity [14]. The methanol extract of aerial parts of the E. hirta shown maximum inhibition of $16 \mathrm{~mm}$ against Bacillus subtilis and maximum inhibition of $23 \mathrm{~mm}$ against Staphylococcus aureus and maximum inhibition of $23 \mathrm{~mm}$ against Escherichia coli and inhibition of $24 \mathrm{~mm}$ against Shigella flexneri and maximum inhibition of $25 \mathrm{~mm}$ against Proteus vulgaris and maximum inhibition of $24 \mathrm{~mm}$ against Micrococcus luteus [15]. The methanol extract of $E$. hirta inhibited the growth organism with the values of $250,375,500$, and $625 \mu \mathrm{g} / \mathrm{mL}$ concentrations (Table 4 and Fig. 4).

\section{Antipsoriasis activity \\ MTT assay}

The fruit and leaf extracts of Solanum erianthum showed inhibitory effect on cancer cell lines [16] in in vivo studies. The cytotoxic activity of methanol extracts of E. hirta on the HaCaT cell line result. The cell viability assay was measured by the MTT reduction assay method as described by Mossman with slight modification. After treatment, the cells were incubated with MTT $(10 \mu \mathrm{L}, 5 \mathrm{mg} / \mathrm{mL})$ at $37^{\circ} \mathrm{C}$ for $4 \mathrm{~h}$ and then with DMSO at room temperature for $1 \mathrm{~h}$. The plate was read by a scanning multiwell spectrophotometer at $595 \mathrm{~nm}$. The MTT assay is a colorimetric assay for assessing cell metabolic activity. The MTT in vitro cell proliferation assay is most widely used assay for evaluating the preliminary antipsoriasis activity [17]. This assay gives an indication of the whole cell cytotoxicity, however, to determine the exact molecular target further assays need to be perform enzyme activity that plays the key role in a number of physiological processes and their inhibitors have been found to exhibit antipsoriasis activity. The MTT assay involves in the conversion of the water-soluble MTT to an insoluble formazan. The formazan is then solubilized, and the concentration was determined by optical density at $570 \mathrm{~nm}$. The maximum HaCaT cell death was $83.74 \pm 1.20$ at $250 \mu \mathrm{g} / \mathrm{mL}$ concentration of methanol extract of aerial parts of the E. hirta, and the $\mathrm{IC}_{50}$ was $12.20 \mu \mathrm{g} / \mathrm{mL}$ concentration.

$\%$ cell viability $=\frac{A_{570} \text { of treated cells }}{A_{570} \text { of control cells }} \times 100$

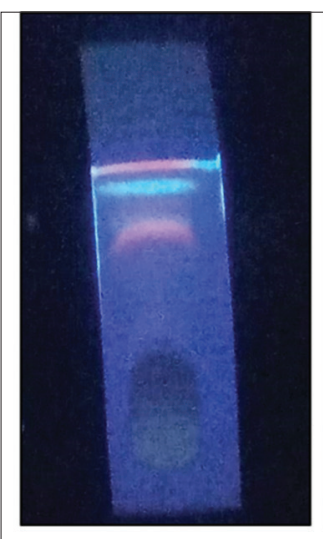

A: UV@ 234nm

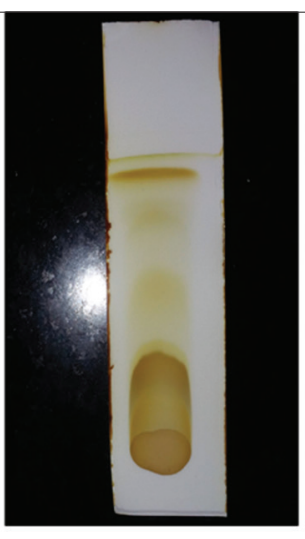

B: Iodine Stain
Fig. 3 Thin-layer chromatography (TLC) (natural substance separated in TLC was acidic, basic, ethyl acetate, methanol, iodine, and toluene) aerial parts of Euphorbia hirta
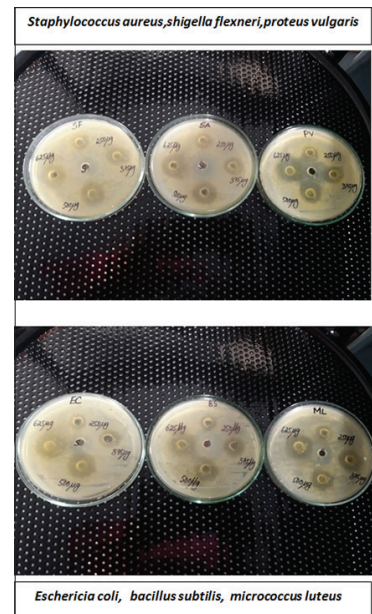

Fig. 4 Antimicrobial activity of methanol extract of aerial parts of Euphorbia hirta. The zone formation in the Petri plate was inhibited the against the microorganism

All data were reported as mean \pm standard deviation. Results of methanol extract of aerial parts of E. hirta were tabulated in Table 5 (Figs. 5 and 6).

\section{ACKNOWLEDGMENTS}

The authors are thankful to Dr. C. Sivaraj, Armats Biotek Training and Research Institute, Guindy, Chennai, for his extreme support and valuable guidance in successful completion of the project within the stipulated period of time. We all confirmed that the manuscript has been read and approved by all named authors and declared that this manuscript is original. 

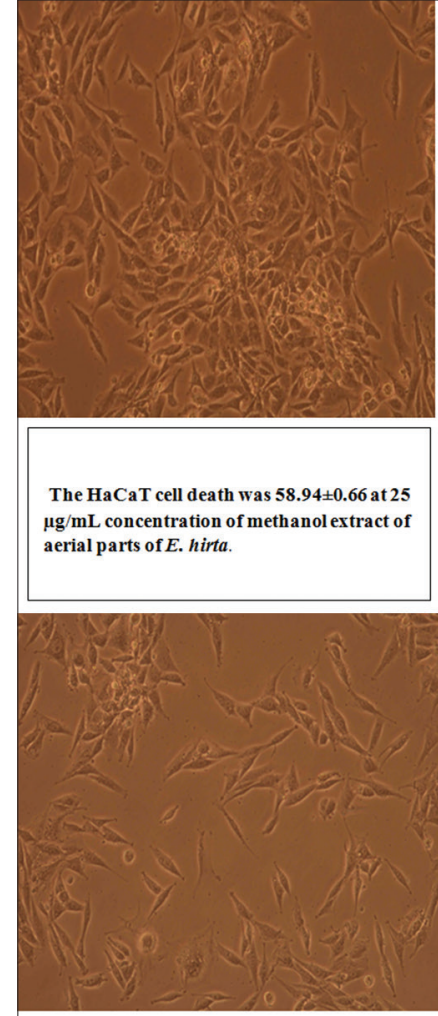

The $\mathrm{HaCa}$ T cell death was $77.73 \pm 1.62$ at $100 \mu \mathrm{g} / \mathrm{mL}$ concentration of methanol extract of aerial parts of $E$. nirta.

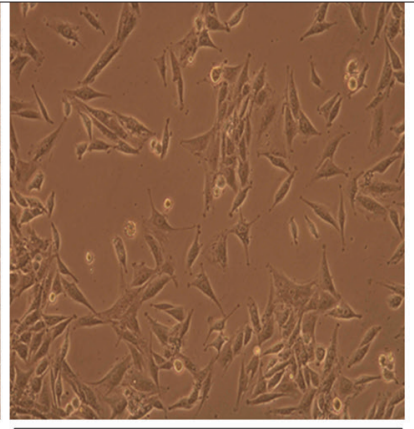

The HaCaT cell death was $64.35 \pm 1.42$ at 50 $\mu \mathrm{g} / \mathrm{mL}$ concentration of methanol extract of aerial parts of $E$. hirta.

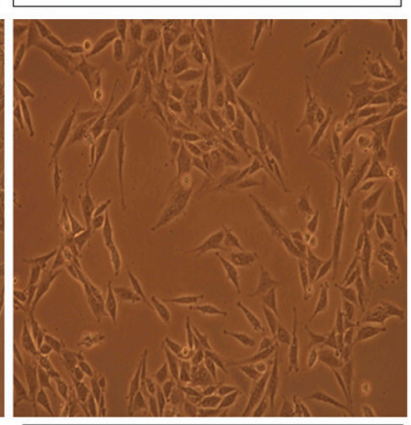

The maximum $\mathrm{HaCaT}$ cell death was $83.74 \pm 1.20$ at $250 \mu \mathrm{g} / \mathrm{mL}$ concentration of methanol extract of aerial parts of E. hirta.

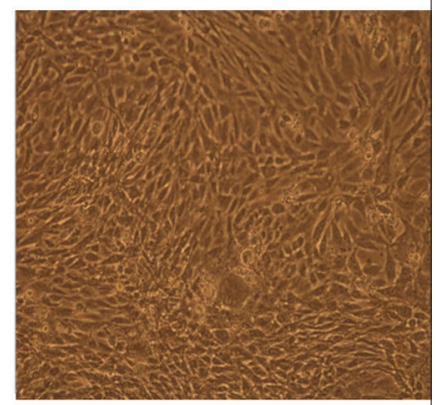

This is control of $\mathrm{HaCaT}$ cell

Fig. 5 Antipsoriasis (3-[4,5-dimethylthiazol-2-yl]-2,5 diphenyl tetrazolium bromide assay) activity of aerial parts of Euphorbia hirta

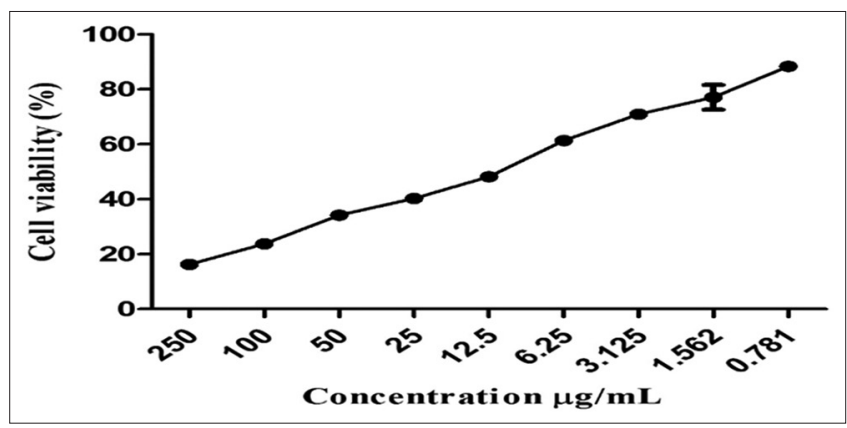

Fig. 6 Antipsoriasis (3-[4,5-dimethylthiazol-2-yl]-2,5 diphenyl tetrazolium bromide assay) the cell viability for aerial parts of Euphorbia hirta

\section{CONFLICTS OF INTEREST}

All the authors declare that there are no conflicts of interest.

\section{REFERENCES}

1. Williamson EM. Major Herbs of Ayurveda. China Churchill Livingstone; 2002.

2. Prajapati ND, Purohit SS, Sharma AK, Kumar T. Handbook of Medicinal Plants. Jodhpur, India Agarbios; 2003.

3. Rahuman AA, Gopalakrishnan G, Venkatesan P, Geetha K. Larvicidal activity of some Euphorbiaceae plant extracts against Aedes aegypti and Culex quinquefasciatus (Diptera Culicidae). Parasitol Res 2008;102867-73

4. Huang L, Chen S, Yang M. Euphorbia hirta (Feiyangcao) A review on its ethnopharmacology, phytochemistry and pharmacology. J Med Plants Res 2012;65176-85.
5. Akowuah GA, Zhari I, Norhayati I, Sadikun A. Radical scavenging activity of methanol leaf extracts of Orthosiphon stamineus. Pharm Biol 2008;42629-35.

6. Giannopolitis CN, Ries SK. Superoxide dismutases I. Occurrence in higher plants. Plant Physiol 1977;59309-14.

7. Basma AA, Zakaria Z, Latha LY, Sasidharan S. Antioxidant activity and phytochemical screening of the methanol extracts of Euphorbia hirta L. Asian Pac J Trop Med 2011;4386-90.

8. Vijayalakshmi M, Ruckmani K. Ferric reducing anti-oxidant power assay in plant extract. Bangladesh J Pharmacol 2016;11570-2.

9. Singh G, Kumar P. Extraction and antimicrobial activity of alkaloids of Euphorbia hirta J Pharm Res 2011;41228-30.

10. Tamokou Jde D, Kuiate JR, Tene M, Kenla Nwemeguela TJ, Tane P. The antimicrobial activities of extract and compounds isolated from Brillantaisia lamium. Iran J Med Sci 2011;3624-31.

11. Vijayalakshmi A, Geetha M. Anti-psoriatic activity of givotia rottleriformis in rats. Indian J Pharmacol 2014;46386-90.

12. Kagan IA, Flythe MD. Thin-layer chromatographic (TLC) separations and bioassays of plant extracts to identify antimicrobial compounds. J Vis Exp 2014;851-8.

13. Sidambaram RR, Dinesh MG, Jayalakshmi ET. An in vitro study of cytotoxic activity of Euphorbia hirta on Hep 2 cells of human epithelioma of larynx. Int J Pharm Pharm Sci 2011;3101-3.

14. Bindu AR, Rosemary J, Akhila S. Antimicrobial activity of M. minuta extracts. Int J Pharm Pharm Sci 2014;6581-3.

15. Enerva LT, Atienza TV, Glifonea ZR, Villamor OB, Villa NA. Cytotoxicity and antimicrobial property of the extract of Euphorbia hirta (Tawa-Tawa). Open J Soc Sci 2015;3162-70.

16. Mahadevi R, Ramakrishnaiahi H, Krishna V, Deepalakshmi AP, Kumar NN. Cytotoxic activity of methanolic extracts of methanolic extracts of Solanum erianthum. Int J Pharm Pharm Sci 2014;7106-8.

17. Sudhakar M, Ch VR, Rao PM, Raju DB, Venkateswarlu Y. Antimicrobial activity of Caesalpinia pulcherrima, Euphorbia hirta and Asystasia gangeticum. Fitoterapia 2006;77378-80. 